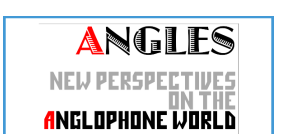

ANELOPHONE WORLI

\section{Angles}

New Perspectives on the Anglophone World

$13 \mid 2021$

The Torn Object

\title{
Video Introduction to Issue 13
}

The Torn Object: Experimentation in Post-War British Literature and Film

\section{Andrew Hodgson}

\section{Q OpenEdition \\ 1 Journals}

\section{Electronic version}

URL: https://journals.openedition.org/angles/4934

DOI: 10.4000/angles.4934

ISSN: 2274-2042

\section{Publisher}

Société des Anglicistes de l'Enseignement Supérieur

\section{Printed version}

Date of publication: 15 December 2021

\section{Electronic reference}

Andrew Hodgson, "Video Introduction to Issue 13", Angles [Online], 13 | 2021, Online since 15

December 2021, connection on 30 December 2021. URL: http://journals.openedition.org/angles/4934 ; DOI: https://doi.org/10.4000/angles.4934

This text was automatically generated on 30 December 2021.

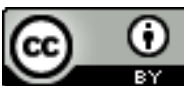

Angles est mise à disposition selon les termes de la Licence Creative Commons Attribution 4.0 International. 


\title{
Video Introduction to Issue 13
}

\author{
The Torn Object: Experimentation in Post-War British Literature and \\ Film
}

\section{Andrew Hodgson}

This media file cannot be displayed. Please refer to the online document http:// journals.openedition.org/angles/4934

\section{Transcript:}

1 The histories of experimentation in anglophone artistic production are something of a rocky terrain. The word 'experimental' itself taking on toxic overtones over the course of the $20^{\text {th }}$ century. As Morton Levitt writes of the British context, "for British authors and critics it has for decades been a pejorative." (Levitt 124) As a critical descriptor, or mode of creation and engagement, it has long been avoided in favour of the more general 'innovative,' the more ideologically loaded 'modernist'; the more ephemeral 'avant-garde.' The application of any of which presents limitations when attempting to address the histories of what might be termed 'critical representation,' or the 'aesthetically challenging' in artistic production in the anglophone cultural sphere since the mid- $20^{\text {th }}$ century. However, in recent years this toxicity has begun to be critically questioned, and the artistic artefacts and experimental modes of production lost in these liminal spaces within/between the descriptors of innovative or modernist or avant-garde have begun to reappear in criticism and publication / showing / retrospective as result of this process of reassessment.

2 If the current reassessments anglophone cultural history is undergoing has centred renegotiations of established canon artefacts, and canon theories of those artefacts, this special issue seeks to expand that reassessment into the wider modes of engagement with experimental production, object and reception, that growing critical spotlight has perhaps indicated, or revealed beyond the current matter of critical focus. In bringing together wide-ranging observations of experimental material, critical approaches and niched and/or side-lined histories, 'The Torn Object' presents a body of critical work that forms new avenues of thought in our understandings of post-war, chiefly British, artistic representation. 
Six of the eight following articles were first presented at the international conference 'Reconnecting Text and World: Re-reading The British Experimental Novel at Post-War' that took place in the semi-fittingly named Georges Perec Auditorium at Université Paris Est-Marne-la-Vallée on the $18^{\text {th }}$ and $19^{\text {th }}$ of April 2019. As the title suggests that conference focused on the experimental novel in post-war Britain. Of particular focus in the papers were figures vaguely coalescing into an amorphous sort of grouping in the late-1960s and early-1970s, or at least critically assigned as such a posteriori. Carrying that spotlight forward into this publication, the following articles focus primarily on B.S. Johnson, Ann Quin, and Brigid Brophy. Other figures from that grouping similarly make their appearance, and adjacent texts are brought into this sphere through comparisons with Muriel Spark, Christine Brooke-Rose, and outside the immediate temporality of this grouping, Stewart Home. These observations of the experimental novel of the period are here joined by two articles that observe experimentation on screen, looking to London Film-Makers Co-operative (LFMC) members Mike Leggett and Ian Breakwell's short film Sheet (1970), and the presentation of Samuel Beckett's later film work largely in the British context.

4 The title of that conference is an underlying driver of the articles that appear here in a number of ways. The first, to reconnect this much-beleaguered term experimental to a constructive use in critical discourse. The second, reconnecting the figures and artefacts of the post-war years in the British context to the social conditions of their emergence, from which they have long been divorced. The third, in doing so, to help return this corpus to some semblance of understanding as a viable artistic culture, and a legitimate presence in recent cultural history. These are points myself and the contributors to this special issue have written and spoken on before, and will continue to do so. And yet these reapproaches are still emergent, in a process of critical flux, and so here I will not endeavour to over-code the window within which the following articles are to be viewed. I will not define here the experimental in literature or film, nor how these entities might be re-established in critical discourse around post-war British, and wider anglophone, cultural history, but leave these inferences to emerge from the reading of the following eight voices as they follow their avenues of thought into the subject.

5 There is more work to be done in this field, and here with this contribution we lay new groundwork for that continuing labour.

\section{BIBLIOGRAPHY}

Levitt, Morton. The Rhetoric of Modernist Fiction: From a New Point of View. Lebanon NH: The University of New England Press, 2006. 


\section{ABSTRACTS}

This issue of Angles investigates experimentation in anglophone artistic production in post-war British literature and film.

Ce numéro de Angles s'intéresse à l'expérimentation artistique anglophone dans la littérature et le cinéma de la post-guerre en Grande-Bretagne.

\section{INDEX}

Keywords: research, literature, experimental art, Great Britain, film, experimental film, postwar, experimental literature, avant-garde

Mots-clés: recherche, littérature, art expérimental, Grande-Bretagne, film, film expérimental, post-guerre, littérature expérimentale, avant-garde

\section{AUTHOR}

\section{ANDREW HODGSON}

Andrew Hodgson is author of the monographs The Post-War Experimental Novel: British and French Fiction, 1945-75 (London: Bloomsbury Academic, 2019) and the forthcoming Surrealist Textualities (London: Bloomsbury Academic, 2023), and the novel Mnemic Symbols (Manchester: Dostoyevsky Wannabe, 2019). He is editor of the experimental writing collections Paris (Manchester: Dostoyevsky Wannabe, 2019) and Praxis (Manchester: Dostoyevsky Wannabe, 2021). He has presented creative and critical work and participated in art exhibitions in France, UK, Ireland, US, Czechia, and Austria. He teaches at the École des Hautes Études en Sciences Sociales (EHESS), Paris. Website: https://www.andrewhodgson.fr. Contact: andrew.hodgson [at] ehess.fr 